\title{
Incorporating Communicative Competence in Assessment and English Language Teaching in Multilingual Settings
}

\author{
Ella Yuzar \\ State Islamic University of Ar-Raniry, Banda Aceh, Indonesia \\ ellayuzar@gmail.com
}

\begin{abstract}
ARTICLE HISTORY
Received : 2020-03-31

Revised : 2020-04-10

Accepted : 2020-04-18
\end{abstract}

\section{KEYWORDS}

Communicative competence

Language teaching

Language assessment

Multilingual settings

\begin{abstract}
There has been a high level of agreement among scholars that communicative competence should be integrated within language learning and assessments. This study unravels the issues of how communicative competence can be assessed and measured in multilingual environments and how the testing can be promoted. Using content analysis approach as the qualitative method, it begins with the historical review of communicative competence from 1970s to the most current concept involving intercultural communicative competence. Then, some practical models of communicative competence that can be used to propose a measurement of communicative competence are presented. Later, this article argues that there is an upsurge need to shift the paradigm of language testing and language assessment towards communicative competence. Moreover, the nature of language testing should not only concern linguistic or knowledge competence but also recognize the different varieties of English. This study implies that, in the field of language testing, language test designers should encompass the concept of communicative competence in the test construct to include real-life language use, and by extension, to increase test validity. As for teachers, a reform integrating communicative competence in classroom language assessment has become essential within the scope of language teaching.
\end{abstract}

\section{Introduction}

The expansion of global communication and mobility has culminated the use of English in the multilingual and multicultural environments. The notion of communicative competence has become a demanded skill in communicating in the 21 st century. Communicative competence as the central importance of acquiring a second language enables the international community to communicate and interact effectively with speakers from different languages and cultural backgrounds (Savignon, 2018).

However, one of the essential questions that remain is how to incorporate communicative competence in assessing and teaching languages. As this is happening, the position of English spoken by its native speakers as the indicator of standardized language test has also been challenged by the existing and emergent English varieties in the real-life context (Edwards \& Fuchs, 2019; Laitinen, 2018; Tickoo, 2020). For example, world-level higher educational institutions have been admitting more international students, and global companies have been flocked with transnational expats. Curriculum, teaching method, classroom climate, and other aspects of language learning are already undergoing adjustment for multicultural environments (Derin \& Hamuddin,
2019; Mena \& Rogers, 2017; Sleeter \& Carmona, 2017). It is incongruous if the assessment in language testing and teaching is still inflexible or limited to the scope of the linguistic structure without contemplating the ability to communicate properly in multilingual settings. Therefore, this current study aims to address the question of how to assess communicative competence and promote communicative language testing in the new paradigm of second language testing. To achieve this aim, the article begins with the historical review of communicative competence and its controversies among scholars. Next, the useful frameworks or models used to assess communicative competence are introduced. Then it continues with the current debates or studies in this area and the implication for language teaching and testing. The paper concludes with a recommendation for future research about topics related to communicative competence, language learning assessment, and multicultural learning environments.

\section{Literature Review}

This section of the paper is a fixture for reaching out the agreement for the demands to integrate language teaching and assessment with communicative competence. How the term was 
originated and then debated by scholar is presented, and the selections of theoretical frameworks are provided for considerations. Finally, it concludes with the amplified controversies in the breadth of communicative competence as well as its implication for teaching and by extension, assessing language.

\subsection{The Historical Review of the Concept and Controversies of Communicative Competence}

The idea of communicative competence was first coined by Hymes (1972), as a response to his dissatisfaction of Chomsky's (1965) term of grammatical competence. For Chomsky, competence means the shared knowledge between the ideal speaker and listener established in a homogeneous speech community and linguistic or grammatical ability becomes the only concern for language performance. Competence is measured by the ability of learners to produce knowledge of a language structure. In opposed to this, Hymes considers grammatical competence and Chomsky's description of the performance is too confined to describe the entire actual language behaviour and thus cannot reflect the actual competence.

Later, Hymes (1972) introduces the term communicative competence and defines it as a knowledge of the rules for understanding and producing both the referential and social meaning of language. He considers that social aspect is as essential as part of the linguistic knowledge in which linguistics competence help learners to understand and produce grammatically correct sentences. While for communicative competence help to understand and produce sentences that are more meaningful, appropriate and acceptable according to particular situations.

In a similar vein, Widdowson (1978) asserts that "we do not only learn how to compose and comprehend correct sentences as isolated linguistic units of random occurrence; but also, how to use sentences appropriately to achieve communicative purposes (p.2)". He perceives language learning not only as understanding the knowledge of a set of grammatical rules but also including the ability to convey messages or communicate the language to others. Additionally, acquiring a language does not only means having the ability to understand how to recognize words and sounds, speak, and write word stocks but it also means the ability to use those phrases properly depending on particular speech situations. Widdowson (1973) also claims that giving English instruction for six or more years does not guarantee learners' ability to communicate as the idea of that 'once competence is acquired, performance will compensate' is not acceptable. Further, he suggests that communicative skills must be learned along with the linguistic skills; otherwise, the acquisition of only linguistic skills may hinder the development of communicative abilities.
However, the realities of English as lingua franca (ELF), globalization, and intercultural communication have challenged these two original assumptions. Although Chomsky's and Hymes's proposal of language competence are different in many ways, the two theorists still do not consider how to achieve effective communication in multilingual and multicultural societies with the accompanying language structure knowledge, skills, and attitude. The challenge of integrating these components, i.e. linguistic ability, skills, and attitude, has been embraced and extensively developed by the intercultural studies in language teaching and learning.

At this point, Byram (1997) developed intercultural communicative competence (ICC), which was not to reject the Hymes's notion of communicative competence but to extend the approach by including the intercultural dimension of using a foreign language. This extension combines the elements of communicative competence with a range of language knowledge and skills, attitudes towards people from different backgrounds, required in the interaction with those from other cultures. An example of the need for intercultural communicative competence can be observed from Brown's (2009) ethnographic study that reports on communication barriers among local and international students at British universities. She further explains that the host students hold a crucial role in helping international students not only to communicate with linguistically appropriate English but also to understand the important social that would make them able to adjust to the local student community. For instance, a Brazilian student was told not to.

"Look at a woman in a straightforward way, or you will get slapped. When I said, 'oh why?' he said, 'because you're not expected to, you don't do that.' He was English, talking about English women, you see. I didn't know that before!" (Brown, 2009, p. 443)

It also proves the importance of involving awareness of culture varieties, the ability to recognize different cultures, and the ability to intercede between them in language teaching and assessment. More importantly, the insufficient merely native speaker model was replaced with an alternative model of the 'intercultural speaker' (p. 31). Just as Young \& Sachdev (2011) confirmed in their study that both students and teacher are in a tendency of adapting and applying Intercultural Communicative Competence in their classrooms. However, even though Byram's ICC has included the multi-voiced cultural notions in foreign language learning, it remains narrowly linked to the association of different nations and cultures in a binary distinction. Therefore, the composition of ICC, which is based on nationalist grouping of culture, might still be disputed in term of communication on a more global scale. 
Kramsch (2006) also perceives that the concept of communicative competence is not enough in new realities of communication in the global age in which language learners are now likely to interact with only a native speaker coming from one identifiable national culture. It also speakers who grew up with multilingual, cultures, and language varieties. Therefore, she offers the notion of symbolic competence as a broader and more reflexive perspective of communicative competence also intercultural communicative competence (Baker, 2016). She then defines symbolic competence as "the ability to read and interpret spoken and written discourse, identify the symbolic value of words and metaphors, grasp their social and historical significance, contrast them with metaphors in one's own language, and reframe one's interpretation of events" (2010, p. 24). Kramsch does not ignore the element of communicative competence as the symbolic competences enrich the sophisticated ability to interpret and negotiate meaning which language learners need in communication in the universal context. In their study, Kramsch \& Whiteside (2008) further explain that symbolic competence is not a mere element of communicative competence nor another skill that needed to be mastered by language learners. It is considered as the ability to monitor mind set, ideology, identity, and position of others in term of what is required at the moment of the speech event. In other words, symbolic competence is the most recent and contemporary way of understanding communicative and intercultural competence in multilingual environments.

\subsection{The Frameworks of Communicative Competence}

Following Bagarić \& Djigunović (2007), there are three models that have become the fundamental grounds of empirical and theoretical research on communicative competence. The first is the framework proposed by Canale \& Swain (1980). In a similar vein to Hymes (1972), their first model incorporates three main components of language and skills, i.e. grammatical, sociolinguistic and strategic competence, which Canale (1984) later switch some elements of sociolinguistic into discourse competence. For them, grammatical competence enables the learner to understand and use linguistic knowledge to express the literal meaning of utterances. This component involves semantics, phonetics, syntactic, morphological and vocabulary knowledge. Regarding the sociolinguistic competence, Canale \& Swain take into account Hymes' concept of language use appropriateness in a variety of social contexts.

Moreover, this competence assesses learners' ability of language use comprehension in particular sociolinguistic or sociocultural situations. The strategic competence, which Canale (1983) highlights as the component that can enhance the effectiveness of communication, involves the knowledge of verbal and nonverbal communication strategy that can reduce communication breakdown. It includes repetition, paraphrase, reluctant, modification of messages, etc. Finally, discourse competence is the ability to communicate using coherent and cohesive language production that establishes meaningful spoken and written texts. It can be examined by learners' use of cohesive devices such as pronouns, conjunctions, parallel structure, etc. in order to form a logical relationship between a groups of sentences.

Designing a more complex, comprehensive and precise framework than the previous model, Bachman and Palmer (1996) propose two broad areas that comprise language ability, i.e. language knowledge and strategic competence. There are two main components of language knowledge, namely, organizational and pragmatic knowledge that complement each other for the purpose of effective language use. In this model, organizational knowledge is the ones that control the use of formal language, which consists of grammatical knowledge and textual knowledge. Grammatical knowledge consists of the comprehension of vocabulary, syntax, phonology, morphology, etc., which assess language learners' in understanding and producing grammatically correct sentences.

On the other side, textual knowledge is the knowledge to produce coherent spoken or written text. It covers learners' ability in choosing the appropriate cohesion devices such as conjunctions, paraphrase, coordinating words etc. and ability to address the topic with a suitable type of text such as composing narrative texts, description, argumentation, causation, etc. In case of pragmatic knowledge, it covers two areas of competence; first is the ability to express and interpret particular language function and second is the ability to understand and create certain linguistic conventions that are proper in a particular context.

The third framework is the model of communicative language competence presented within CEF or Common European Framework (2001), which was designed to aim for language assessment as well as for language teaching and learning. In this model, communicative competence is perceived in three basic components, i.e. language competence, sociolinguistic competence and pragmatic competence. Language competence which includes grammatical competence enables language learners to apply the knowledge of language content such as lexical, semantic, phonological, grammatical competence in producing structured utterances. Sociolinguistic competence enables learners to express appropriate language use in the particular social context, and pragmatic competence underlines two abilities, i.e. discourse competence and functional competence. 
In sum, these frameworks and theories regarding communicative competence are to provoke language educators and test designers to visualize the ability to understand communication beyond language as a restricted feature.

\subsection{Current Debates in Assessing Communicative Competence}

The previous section reviews the historical development of the communicative competence in relation to second language teaching, learning, and testing by focusing and elaborating on the influential perspectives of communicative competence and its framework that could be used to design a way to assess learners' communicative competence. The discussion of the current debates on communicative competence will look upon two key issues. First is the assessment of communicative competence in the classroom setting. Second is the raised problem in assessing communicative competence in a high stake or standardized language testing.

Concerning communicative competence in the classroom setting, two main issues occur in language assessment. First is, the contradictive goal of language curriculum and the need for communicative competence (Derin, Nursafira, Yudar, Gowasa, \& Hamuddin, 2020). Most educational institutions, ranging from secondary school to graduate programs at university, merely emphasize the writing ability. Most school and university assignments do not involve oral competence as their assessment indicators. There is an imbalance development on the oral task and the written task. As a result, there is not a sufficient framework or model to assess communicative competence.

Regarding this, Oliver, Haig, \& Rochecouste (2005) report on the teaching and assessment of oral task in a secondary school in Western Australia. They explain that the teachers found difficulty in assessing students' oral task due to the curriculum bias toward writing skill. Teachers admit that they do not have the skills and guidance for assessing communicative skills even though the teachers and the students feel they need to require communicative competence. Besides, Canagarajah (2006) also finds that there is a need of changing pedagogical priorities from the reliance of discrete-item test on formal grammatical competence to the development of instruments that are able to assess performance and pragmatics. He also emphasizes that "the new assessment would focus on strategies of negotiation, situated performance, communicative repertoire, and language awareness," (p. 229). On the other hand, the theory is not the only part that should be reformed. Savignon (2018) argues that rectification in classroom practice should also be encouraged. Teachers need to collaborate with the institutional support in assisting both pre-service and in-service teachers in improving their capability for integrated communicative teaching.
The field of standardized language testings, Harding (2014) also assert that there is an urgent need to shift the nature of language testing from being narrowly linguistic criteria to the test construct that are sufficient to reflect the current communicative needs. In a more recent study, Elder, McNamara, Kim, Pill, \& Sato (2017) report on three studies that investigates language assessment for English in the specific purpose context. Their findings raise almost the same issue of whether the language should and can be assessed objectively and separately from the context as they found in the studies that most of the non-linguistics expertise put little attention on testtakers' accuracy and greater emphasis on participants' communicative ability in transferring the message. Similarly, Morrow (2018) argues that communicative language testing purposes enhance the validity of language test. Such a test should use authentic materials and activities based on test-takers' real language use that measure various types of appropriateness with social, cultural, and pragmatic norms. Even though the construct of communicative language testing is significantly different from the well-established psychometric forms of testing, a movement toward communicative language testing must be promoted.

In sum, drawing from the previous research in this area, this study argues that communicative competence can be assessed by shifting the paradigm of language assessment from only focusing on linguistic or knowledge content to sociolinguistic and pragmatic language testing. Moreover, the new appearance of language testing and language assessment should recognize different varieties of English as a result of communication in the global environment.

\section{Implications for Language Teaching and Testing}

Noticing the improvement in the field of language testing toward communicative competence, the present study argues that second language testing should pose more concern on communicative language testing than merely assess linguistic competence. In order to fulfil the validity requirement, the second language test should also an emphasis on sociolinguistic and pragmatic competence. It includes the test that incorporates different varieties of English as the result of the type of communication needed in the 21 st century. It is in line with Harding's (2014) proposal of "adaptability" in the communicative language testing construct. He further explains that the notion of adaptability is a common measure of "the test takers need to cope with different varieties of English, to use and understand appropriate pragmatics, to cope with the fluid communication practices of digital environments, and to notice and adapt to the formulaic linguistic patterns associated with different 
domains of language use" (p.194). Drawing from the theoretical review and current debates in assessing communicative competence and communicative language testing, the study proposes three implications that might inform the field of language testing.

First, one of the ways to test the validity of a language test can be measured through the argumentbased approach in which the language test is able to represent the language used in the real-life context. Recently, English has been learned and used by millions of people around the world in many settings, including higher educations. There is a number of English varieties that students in higher educations will encounter. High stakes or standardized language test should consider assessing test takers' ability dealing with diverse varieties of English. The test should also incorporate certain communicative abilities as part of the test construct, e.g. ability to express and respond to pragmatics use of language, ability to tolerate potentially unfamiliar language varieties, ability to negotiate to mean and avoid communication breakdown, ability to communicate with interlocutor from different language background and culture, ability to use appropriate discourse data whether in spoken or written text.

Second, communicative language testing and assessment can incorporate a variety of communicative test instruments. For example, language use can be assessed through a carefully designed and interactive role-play. In this way, the test examiner might be able to assess the test takers' use of correct language structure as well as the appropriate use of language pragmatics. A role-play activity that includes roles having different positions and social status can be used to assess language learners' sociolinguistic competence. Another sample activity is the study of Yamashita (2001), who explores the usefulness of Bachman \& Palmer's (1996) picture response test (PRT). He utilizes this method instead of writing of recorded verbal audiolingual prompt to draw on pragmatic behaviour.

Third, language classroom assessment could integrate innovative tasks with technology-enhanced language teaching and testing by using blogging, social networks, wikis, and other types of digital spoken or written communication. The possible tasks that teachers could incorporate to measure language performance are collaborative writing and note-taking, multimodal comprehension, video conferences, etc. For example, Kung (2016) has proved that the use of a media literacy approach, such as by giving students the exposure of authentic online news items might help increase their oral communicative competence. This way of teaching and assessing language will reflect the real context of language use and the new literacies, as nowadays, communication has been done more through electronic devices.

\section{Agenda for Further Research}

To further examine how to measure and assess communicative competence in the field of language testing, a longitudinal study that investigates the development of English language use, especially in the academic environment, should be conducted. Also, an ethnography study in the multilingual classroom can be done to obtain further explanation and examination of language use in the real context. The result of this study later might inform language test designer in constructing a language test that can assess not only linguistic content or knowledge but also communicative competence. This study will also notify language teachers related to the target and goal in the language testing preparation classroom. Another study that proposes a multilingual language testing should be conducted. A language test construct that includes different varieties of English can be designed and piloted in order to develop a new paradigm of communicative language testing.

\section{Acknowledgement}

This paper was initially a research paper assignment when the author was undertaking a master program. The writer of this article is immensely grateful to Dr. Chloé Diskin from University of Melbourne for her objective comments and suggestions in the original manuscript.

\section{References}

Bachman, L. F., \& Palmer, A. S. (1996). Language Testing in Practice: Designing and Developing Useful Language Tests. Oxford etc.: OUP.

Bagarić, V., \& Djigunović, J. (2007). Defining communicative competence. METODIKA: časopis za teoriju $i$ praksu metodika $u$ predškolskom odgoju, školskoj i visokoškolskoj izobrazbi, 8(14), 94-103.

Baker, W. (2016). Culture and language in intercultural communication, English as a lingua franca and English language teaching: Points of convergence and conflict.

Brown, L. (2009). A failure of communication on the cross-cultural campus. Journal of Studies in International Education, 13(4), 439-454.

Byram, M. (1997). Teaching and assessing intercultural communicative competence. Clevedon: Multilingual Matters.

Canagarajah, S. (2006) Changing Communicative Needs, Revised Assessment Objectives: Testing English as an International Language, Language Assessment Quarterly: An International Journal, 3(3), 229-242 
Canale, M. (1983). From communicative competence to communicative languagepedagogy. In Richards, J. C., \& Schmidt, R. W. (Eds.), Language and Communication, 2-27. London: Longman.

Canale, M. (1984). A communicative approach to language profi ciency assessment in a minority setting. In Rivera, C. (Ed.), Communicative competence approaches to language proficiency assessment: Research and application, 107-122. Clevedon: Multilingual Matters.

Canale, M., \& Swain, M. (1980). Theoretical bases of communicative approaches to second language teaching and testing. Applied linguistics, 1(1), 147.

Council of Europe. Council for Cultural Co-operation. Education Committee. Modern Languages Division. (2001). Common European Framework of Reference for Languages: learning, teaching, assessment. Cambridge University Press.

Derin, T., \& Hamuddin, B. (2019). Foreign Language Classroom Anxiety, and Enjoyment During Study Abroad: A Review of Selected Paper. Lisan: Jurnal Bahasa dan Linguistik, 8(2), 76-82.

Derin, T., Nursafira, M. S., Yudar, R. S., Gowasa, N. S., \& Hamuddin, B. (2020). Persuasive Communication: What Do Existing Literature Tells Us About Persuasive Communication Among Students?. Utamax: Journal of Ultimate Research and Trends in Education, 2(1), 12-18.

Edwards, A., \& Fuchs, R. (2019). Varieties of English in the Netherlands and Germany. English in the German-speaking World, 267.

Elder, C., McNamara, T., Kim, H., Pill, J., \& Sato, T. (2017). Interrogating the construct of communicative competence in language assessment contexts: What the non-language specialist can tell us. Language \& Communication, 57, 14-21.

Harding, L. (2014). Communicative language testing: Current issues and future research. Language assessment quarterly, 11(2), 186-197.

Hymes, D. (1972). On communicative competence. Sociolinguistics, 269-293.

Kramsch, C. (2006). From communicative competence to symbolic competence. The modern language journal, 90(2), 249-252.

Kramsch, C. (2010). Theorizing translingual/transcultural competence. In G. Levine \& A. Phipps (Eds.), Critical and intercultural theory and language pedagogy (pp. 15-31). Boston, MA: Heinle.

Kung, F. W. (2016). Facilitating learners' second language communicative competence through the development of media literacy: A conversation analytic approach. The AsiaPacific Education Researcher, 25(2), 337-346.

Laitinen, M. (2018). Placing ELF among the varieties of English. Modeling World Englishes: Assessing the Interplay of Emancipation and Globalization of ESL Varieties. Amsterdam: Benjamins, 109-131.

Mena, J. A., \& Rogers, M. R. (2017). Factors associated with multicultural teaching competence: Social justice orientation and multicultural environment. Training and Education in Professional Psychology, 11(2), 61.Mena, J. A., \& Rogers, M. R. (2017). Factors associated with multicultural teaching competence: Social justice orientation and multicultural environment. Training and Education in Professional Psychology, 11(2), 61.

Morrow, C. K. (2018). Communicative language testing. The TESOL Encyclopedia of English Language Teaching, 1-7. doi.org/10.1002/9781118784235.eelt0383.

Oliver, R., Haig, Y., \& Rochecouste. (2005). Tackling talk : teaching and assessing oral language. Edith Cowan University: Perth, Australia. Retrieved from: https://ro.ecu.edu.au/ecuworks/7126.

Savignon, S. J. (2018). Communicative competence. The TESOL encyclopedia of English language teaching, 1-7.

Tickoo, A. (2020). An emergent English-mediated identity and a Chinese variety of WE. Pragmatics and Society, 11(1), 70-95.

Widdowson H.G. (1973) "Directions in the Teaching of Discourse", in Corder S. P. \& E. Roulet (eds.) Theoretical Linguistic Models in Applied Linguistics, Brussels: AIMA.

Widdowson, H.G. (1978). Teaching Language as Communication. London: Oxford University Press.

Yamashita, S. (2001). Using pictures for research in pragmatics: Eliciting pragmatic strategies by picture response tests. A Focus on Language Test Development (pp. 35). Honolulu: University of Hawai ' $i$ at Manoa, National Foreign Language Resource Center.

Young, T. J., \& Sachdev, I. (2011). Intercultural communicative competence: Exploring English language teachers' beliefs and practices. Language awareness, 20(2), 81-98. 